\title{
The role of short-time work schemes during the global financial crisis and early recovery: a cross- country analysis
}

\author{
Alexander Hijzen ${ }^{1 *}$ and Sebastien Martin ${ }^{2}$
}

\author{
* Correspondence: alexander. \\ hijzen@oecd.org \\ ${ }^{1}$ OECD and IZA, Paris, France \\ Full list of author information is \\ available at the end of the article
}

\begin{abstract}
There has been a strong interest in short-time work (STW) schemes during the global financial crisis. Using data for 23 OECD countries for the period 2004 Q1 to 2010 Q4, this paper analyses the quantitative effects of STW programmes on labour market outcomes. Special attention is given to the dynamic aspects of the relationship between output shocks and labour market outcomes. The results indicate the STW raises hours flexibility by increasing the output elasticity of working time and helps to preserve jobs in the context of a recession by making employment and unemployment less elastic with respect to output. A key finding is that the timing of STW is crucial. While STW helped preserving a significant number of jobs during the crisis, its continued use during the recovery may have slowed the job-content of the recovery. By the end of 2010, the net effect of STW on employment was negligible or may even have become negative. However, the gross impact of STW on the number of jobs saved per quarter remains large and positive in the majority of countries.
\end{abstract}

JEL codes: J23; J65; J68

Keywords: Global financial crisis, Partial unemployment benefits, Work sharing

\section{Introduction}

Short-time work (STW) programmes are public schemes that are intended to preserve jobs at firms experiencing temporarily low demand by encouraging work-sharing, while also providing income-support to workers whose hours are reduced due to a shortened workweek or temporary lay-offs. A crucial aspect of all STW schemes is that the contract of an employee with the firm is maintained during the period of STW or the suspension of work. The main purpose of STW schemes is to avoid "excessive" layoffs, that is, the permanent dismissal of workers during an economic downturn whose jobs would be viable in the longer-term. In an environment where firms are risk-neutral and they can fully insure their employees, excessive layoffs are effectively ruled out (Burdett and Wright, 1989). However, in an environment where firms are financially constrained, as during a credit crunch, a well-designed STW scheme may help to increase welfare (Braun et al., 2011). Moreover, STW schemes may also help to improve equity by sharing the burden of adjustment more equally across the workforce (OECD, $2009)^{1}$.

\section{Springer}

(c) 2013 Hijzen and Martin; licensee Springer. This is an Open Access article distributed under the terms of the Creative Commons Attribution License (http://creativecommons.org/licenses/by/2.0), which permits unrestricted use, distribution, and reproduction in any medium, provided the original work is properly cited. 
There has been a strong interest in STW schemes during the global financial crisis in OECD countries. Most governments in countries with existing schemes took specific measures in response to the crisis to promote their use, while several others established new ones. The interest among firms and workers in STW schemes, as measured in terms of take-up, also tended to be substantial. Across the 25 OECD countries that operated a STW scheme during the global financial crisis, take-up increased from a negligible amount in 2007 to over 1\% of dependent employment in 2009. This corresponds to over 4.5 million workers across the OECD. However, the use of STW differed substantially across countries. At its peak, take-up amounted to over 7\% in Belgium, around 4 to $5 \%$ in Germany and Japan and around 1 to 2\% in Austria, Czech Republic, France, Ireland, Italy, the Netherlands, and Slovakia. In other countries with STW schemes it remained below 1\%. The use of STW declined considerably during 2010 as a result of the initial economic recovery, with the decline in the use of STW in response to the improvement in economic conditions in the early recovery being similar to the increase in response to the deterioration in aggregate demand during the crisis $^{2}$.

Given the size and prominence of STW schemes during the global financial crisis, it is important to evaluate their impact. Two approaches have been used: firm-level and country-level approaches. The basic idea of firm-level studies is to assess the causal impact of STW by comparing outcomes of firms that make use of STW with those of comparable firms that do not. The main challenge is to overcome the selection problem that arises because firms that participate in STW schemes tend to be less competitive than other firms that can serve as a control group. As this turns out to be very difficult in practice, many previous firm-level studies have either concluded that STW is counter-productive or that it is not possible to overcome the selection problem with the available data ${ }^{3}$. The study by Boeri and Brucker (2011) represents a notable exception. They propose a plausible instrument based on the experience of firms with STW before the crisis. This is a valid instrument as long as prior use is a good predictor of use during the crisis and output demand shocks during the crisis are uncorrelated with shocks before the crisis, which appears to be the case. They find that STW increases employment growth and that the effect increases in size once the endogeneity of STW with respect to employment growth is taken into account. Unfortunately, using the same data and a similar strategy, but a somewhat more sophisticated specification, Bellman et al. (2012) were unable to confirm these results. As most other firm-level studies, their results indicate that STW increases the output elasticity of employment, possibly due to a problem of weak instruments.

In the light of the mixed success of firm-level studies in identifying the causal impact of STW, aggregate approaches in the spirit of Abraham and Houseman (1994) and Van Audenrode (1994) provide a potentially fruitful alternative. Hijzen and Venn (2010) provide an early assessment of the impact of STW schemes on preserving jobs during the crisis. Their estimates support the conclusion that STW schemes had an economically important impact, with the largest impacts of STW on employment in Germany and Japan among the countries considered. However, the positive impact of STW was limited to workers with permanent contracts, thereby further increasing labour market segmentation between workers in regular jobs and workers in temporary jobs. The estimated jobs impact was smaller than the potential number of jobs saved as implied by the full-time equivalent number of participants in STW. This suggests that STW schemes end up supporting some jobs that would have been maintained in the absence 
of the subsidy. Subsequent studies by Boeri and Brucker (2011) and Cahuc and Carcillo (2011), who make use of largely the same dataset but employed somewhat different estimation strategies, reached similar conclusions ${ }^{4}$.

This paper also analyses the quantitative effects of STW programmes on employment and hours by exploiting the country and time variation in STW take-up rates. It provides an update on the initial assessment by Hijzen and Venn (2010) by extending the time and country coverage of the dataset from 2004 Q1-2009 Q3 to 2004 Q1-2010 Q4 and from 19 to 23 countries $^{5}$. The use of more recent data is important as it allows analysing the impact of STW not just during the crisis, but also during the early phase of the recovery. The econometric analysis takes account of differences in institutional settings across countries that might affect the relationship between labour market outcomes and output and addresses the potential endogeneity of STW take-up with respect to labour market conditions using the age of the programme as an instrument. Moreover, special attention is given to model the dynamic aspects of the relationship between output, employment and working time.

The remainder of this paper is structured as follows. Section 2 provides information on the institutional features of STW schemes as they operated during the global financial crisis as well as suggestive evidence on the role of these features for take up. Section 3 presents the econometric framework, while Section 4 discusses the data. Section 5 provides a qualitative discussion of the results based on the econometric estimates, while Section 6 discusses their quantitative implications in terms of the number of permanent jobs saved since the start of the global financial crisis. Section 7 presents simple simulations in order to illustrate how the role of STW changes under different assumptions about the persistence of the output shocks and the use of STW during the economic recovery. Section 8 concludes.

\section{Institutional background}

Twenty-five OECD countries operated a STW programme during the global financial crisis. Hijzen and Venn (2010) provide a detailed overview of the main features of STW schemes as they operated during the global financial crisis and show there is considerable variation in their institutional design. To an important extent, this is likely to reflect different strategies for balancing concerns about assuring adequate take-up while maintaining cost-effectiveness. The latter depends on the importance of deadweight and displacement effects. Deadweight effects occur when STW subsidies are paid for jobs that employers would have retained even in the absence of the subsidy, implying that this spending is a pure transfer to firms which does not limit job losses ${ }^{6}$. Displacement effects occur when STW schemes preserve jobs that are not viable without the subsidy, even after business conditions recover, and will be suppressed once the subsidy comes to an end. Following Hijzen and Venn (2010), Table 1 summarises the main features of STW schemes for the 18 countries used in the analysis which operated a STW scheme during the crisis along four key dimensions: work-sharing requirements, eligibility requirements, conditionality requirements and generosity.

- Work-sharing requirements specify the range of permissible reductions in weekly hours for short-time workers. Minimum permissible hours reductions are intended to limit STW participation to firms experiencing important financial difficulties, 
Table 1 The institutional characteristics of short-time work schemes by country

\begin{tabular}{|c|c|c|c|c|c|c|}
\hline & $\begin{array}{l}\text { Difference of } \\
\text { maximum and minimum } \\
\text { permissible reduction } \\
\text { in weekly hours }\end{array}$ & $\begin{array}{l}\text { Strictness of } \\
\text { eligibility criteria } \\
\text { Score in } \%\end{array}$ & $\begin{array}{c}\text { Strictness of } \\
\text { conditionality criteria } \\
\text { Score in } \%\end{array}$ & $\begin{array}{l}\text { Cost to employer } \\
\text { for hours not worked } \\
\% \text { of normal total labour cost for a } \\
\text { single worker without children who } \\
\text { usually earns the average wage }\end{array}$ & $\begin{array}{c}\text { STW Net } \\
\text { replacement rate } \\
\% \text { of the average earnings } \\
\text { for a single worker } \\
\text { without children }\end{array}$ & $\begin{array}{l}\text { Maximum duration } \\
\text { Number of month }\end{array}$ \\
\hline Ausfria & 80 & 67 & 25 & 17 & 55 & 24 \\
\hline Belgium & 100 & 50 & 13 & 0 & 70 & 5 \\
\hline Canada & 40 & 100 & 0 & 0 & 61 & 12 \\
\hline Czech Republic & 100 & 67 & 25 & 25 & 60 & 6 \\
\hline Denmail & 60 & 33 & 13 & 0 & 61 & 6 \\
\hline Finland & 75 & 83 & 25 & 0 & 51 & 100 \\
\hline France & 100 & 67 & 25 & 39 & 75 & 13 \\
\hline Germany & 90 & 100 & 25 & 8 & 60 & 24 \\
\hline Hungary & 80 & 33 & 50 & 0 & 100 & 12 \\
\hline Ireland & 60 & 33 & 25 & 0 & 31 &. \\
\hline Italy & 100 & 33 & 25 & 17 & 83 & 24 \\
\hline Japan & 100 & 100 & 0 & 31 & 66 & 28 \\
\hline Netherlands & 30 & 67 & 50 & 0 & 73 & 13 \\
\hline Norway & 60 & 67 & 25 & 23 & 64 & 12 \\
\hline Poland & 100 & 67 & 50 & 13 & 49 & 6 \\
\hline Portugal & 100 & 33 & 33 & 16 & 72 & 18 \\
\hline Slovak Republic & 96 & 67 & 0 & 48 & 73 & 3 \\
\hline Spam & 67 & 33 & 50 & 0 & 61 & 24 \\
\hline
\end{tabular}

Not available.

Strictness of eligibility requirements: Index based on the following three eligibility requirements to STW schemes: i) justification of economic need for firms; ii) social partner agreement; and iii) obligation for

participating workers to be eligible for UB, which attributes a value of one-third for the presence of each eligibility requirement.

Strictness of conditionality requirements: Index based on the following four conditionality requirements: i) compulsory training; ii) recovery plan; iii) no dismissal; iv) job-search requirement for employee, which attributes a value of 0.25 for the presence of each conditionality requirement.

Source: Hijzen and Venn (2010). Not available. 
while maximum average hours reductions rule out temporary layoffs and foster work-sharing by spreading the burden of adjustment across a larger group of workers.

- Eligibility requirements set conditions that employers or workers must meet in order to participate in STW programmes. The indicator ranges from zero to one and attributes a score of one third, respectively, for requiring a justification of economic need by the firm; the agreement of the social partners; and workers to be eligible for unemployment benefits.

- Conditionality requirements set behavioural requirements for both employers and workers participating in STW schemes. The indicator ranges from zero to one and attributes one quarter for, respectively, requiring workers on short-time work to participate in training; requiring the development of a recovery plan; prohibiting dismissals during, or, for a short period after participation in STW schemes; and, active job search by workers on short-time work.

- The generosity of a STW programme determines the cost of participation for both firms and workers and the maximum length of participation. For firms this depends on the extent to which they are required to share in the cost of hours not worked, while for workers this depends on the extent to which they are compensated for hours not worked (i.e. the replacement rate). Limits to the maximum duration for which STW subsidies are available are likely to play a crucial role in ensuring countries that STW schemes do not end up becoming an obstacle to job creation in the recovery.

In order to get some idea of the institutional features of STW schemes for take-up, we make use of the following dynamic panel data model:

$T_{i t}=\sum_{x=0}^{X} \gamma_{x} T_{i t-1}\left[1+\left(X_{i}-X\right)\right]+\sum_{x=0}^{X} \alpha_{x} \ln y\left[1+\left(X_{i}-X\right)\right]+Z_{i t}+D_{y}+D_{q} * D_{i}+\varepsilon_{i t}$

which expresses the STW take-up rate (T), defined as the share of STW participants in dependent employment, as a function of its past value and the log value of real output (y), the institutional features of STW (X) and a number of controls $(\mathrm{Z}, \mathrm{D})^{7}$. The coefficient on the semi-elasticity of take-up with respect to output, $\alpha_{0}$, measures the responsiveness of take-up to economic shocks, while the coefficient on the lagged dependent value, $\gamma_{o}$, captures the persistence of STW and gives an indication of the time participants spend in STW schemes. Both coefficients are allowed to differ according to the main characteristics of STW schemes by interacting the lagged dependent variable and the output variable with indicators of the institutional features of STW schemes (expressed in terms of deviations from their sample means). Z includes a series of control variables to take account of, respectively, the time STW schemes have been in existence and the broader institutional context in which STW schemes operate. In the present case, the institutional context is taken into account by controlling for any factors that affect STW but do not vary over time through the use of country fixed effects as well as by including a time-varying indicator of the stringency of employment protection. The regressions account for macro-economic changes that are common across countries through the inclusion of year-fixed effects and country-specific seasonality profiles through the inclusion of quarter-times-country dummies. 
In general, there is little evidence of a robust relationship between the institutional features of STW and take up (Table 2). Nevertheless, the analysis provides a number of tentative insights:

- Restrictions on the permissible range of working-time reductions reduce the responsiveness of take-up to changes in output, but increase its persistence. This is likely to primarily reflect the role of minimum requirements on hours reductions since these are typically used as a way to restrict take-up to firms experiencing financial difficulties.

- Eligibility requirements tend to reduce the responsiveness of take-up to output shocks. The negative role of eligibility criteria is likely to be intended as eligibility criteria seek to reduce deadweight losses by limiting the use of STW to firms that really need it. Conditionality requirements are found to increase the responsiveness of take-up to output shocks when included on its own, but this effect disappears when including all key dimensions of STW simultaneously in the regressions.

- There is some evidence that requiring firms to share in the cost of STW reduces the responsiveness of take-up to output shocks. This may help to limit the use of STW to workers that firms would like to keep. However, this effect does not survive when including all key characteristics of STW schemes simultaneously.

- While the maximum duration for which STW subsidies are available and the degree to which employers share in the cost of STW are often considered to be features that help ensure that firms do not use STW subsidies for too long, there is no evidence that these factors reduce persistence.

\section{Econometric methodology}

This paper exploits the country and time variation in take-up rates to analyse the quantitative impacts of STW schemes on labour market outcomes. Exploiting the variation in the intensity with which STW is used across countries and time has a number of advantages. First, exploiting the variation across countries, rather than between participating and non-participating firms within countries, avoids the selection problem that characterises firm-level studies. While it is true that exploiting the country and time variation introduces important new concerns in relation to selection and endogeneity, we argue these can be addressed satisfactorily, whereas this is not always the case at the firm level. Second, the approach used here focuses on the net effects of STW on labour market outcomes, after taking account of its effects on both participating and nonparticipating firms. To the extent that STW also affects labour market outcomes in nonparticipating firms, for example, by reducing labour mobility, this could be potentially important. Thus, in contrast with firm-level studies, country-level studies are not confined to estimating partial equilibrium effects but may also pick up potentially important general equilibrium effects.

\subsection{Static model}

Building on previous work by Hijzen and Venn (2010) and Boeri and Brucker (2011), we adopt an empirical specification that allows the use of STW to have a direct effect on the growth rate of the outcome of interest and an indirect effect through its impact 
on the elasticity of the labour market outcome of interest with respect to output. More specifically, we start off with the following first-difference model:

$$
\Delta l_{i t}=\alpha \Delta \ln y_{i t}+\beta T_{i t}+\gamma \Delta \ln y+T_{i t}+D_{y}+D_{q} *+\varepsilon_{i t}
$$

where $\Delta l$ refers to the quarter-to-quarter change in the log of the labour market outcome of interest, $\Delta \ln y$ to the quarter-to-quarter change in the log of output, $T$ refers to the number of participants in STW as a share of dependent employment. As in the take-up analysis, the regressions also include year and quarter-times-country dummies to control for common macro-economic trends across countries as well as countryspecific seasonality patterns. $\varepsilon$ refers to a random error term. Subscripts $i$ and $t$ refer to country and time. The coefficient $\alpha$ provides an estimate of the elasticity of the labour market outcome of interest with respect to output in countries that do not operate STW schemes. The coefficient $\beta$ provides an estimate of the direct effect of STW on the growth rate of the labour market outcome of interest. The coefficient $\gamma$ provides an estimate of the indirect effect of STW on the elasticity of the labour market outcome of interest with respect to output. This is the main parameter of interest.

In order to explore to what extent the impact of output on the labour market of interest can be summarised by a contemporaneous relationship as in (2a) or whether some of the impact of output only occurs with a lag, the model is also estimated by lagging output changes and STW take-up by, respectively, one and two quarters. As will be shown below, the results for both employment and average hours are rather sensitive to these slightly different specifications, suggesting that modelling the dynamic effects of STW is very important.

\subsection{Dynamic model}

In order to analyse the dynamic effects of the use of STW schemes on labour market outcomes we make use of dynamic regression models that allow both for persistence in the outcome variable of interest as well as lagged responses to changes in output. More specifically, we re-parameterise an autoregressive distributed lag (ARDL) model of order $(1, \mathrm{~s})$ to derive the following augmented error-correction model:

$$
\Delta l_{i t}=\phi\left(l_{i t-1}-\delta \ln y\right)+\sum_{s=0}^{2} \alpha_{s} \Delta \ln y_{i t-s}+\sum_{s=0}^{2} \beta_{s} T_{i t-s}+\sum_{s=0}^{2} \gamma_{s} \Delta \ln y_{i t-s} T_{i t-s}+D_{y}+D_{q} * D_{i}+\varepsilon_{i t}
$$

where $\phi=-(1-\lambda)$ and $\delta=\sum_{s=0}^{2} \alpha_{s} /(1-\lambda) . \lambda$ captures the degree of persistence in the outcome variable of interest, $\delta$ the long-term output elasticity and $\alpha_{s}$ the short-term output elasticity with zero STW at time $t+s$. The model is augmented to allow for a direct impact of STW on the growth rate of the labour market outcome and an indirect effect through its impact on the short-term output elasticity. The $\beta$-coefficients capture the direct effect of a 1 percentage point increase in the take-up rate of STW on the growth rate of the labour market outcome of interest, while the $\gamma$-coefficients capture the impact of a 1 percentage point increase in the take-up rate on the short-term output elasticity. The dummy structure is the same as in the static model.

The general error-correction model described by (2b) is only appropriate for outcome variables that have a stable long-term relationship with output such as employment and total hours worked. However, it is not appropriate for stationary variables which are independent of output in the long-run such as average hours worked. In this case, 
Table 2 The role of institutional characteristics for the use of STW ${ }^{a}$.

\begin{tabular}{|c|c|c|c|c|c|c|c|}
\hline & Model 1 & Model 2 & Model 3 & Model 4 & Model 5 & Model 6 & Model 7 \\
\hline \multirow[t]{2}{*}{ Lagged dependent variable } & $0.689 * * *$ & 0.693 *** & $0.695 * * *$ & $0.658^{* * *}$ & $0.660^{* * *}$ & $0.596 * * *$ & $0.558 * * *$ \\
\hline & $(0.060)$ & $(0.057)$ & $(0.059)$ & $(0.059)$ & $(0.068)$ & $(0.077)$ & $(0.085)$ \\
\hline \multirow{2}{*}{$\begin{array}{l}\text { Number of years since } \\
\text { STW was introduced }\end{array}$} & 0.105 & $0.061 * * *$ & $0.062 * * *$ & $0.078 * * *$ & $0.076^{* * *}$ & $0.066 * *$ & $0.098 * * *$ \\
\hline & $(0.090)$ & $(0.016)$ & $(0.016)$ & $(0.020)$ & $(0.019)$ & $(0.015)$ & $(0.024)$ \\
\hline \multirow[t]{2}{*}{ Log output } & $-4.853 * * *$ & $-4.272 * * *$ & $-4.394 * * *$ & $-4.482 * * *$ & $-4.547 * * *$ & $-4.556 * * *$ & $-5.625 * * *$ \\
\hline & $(1.296)$ & $(1.384)$ & $(1.197)$ & $(1.274)$ & $(1.210)$ & $(1.125)$ & $(1.530)$ \\
\hline \multirow[t]{2}{*}{ Strictness of employment protection } & $0.521 * *$ & $0.463 * *$ & $0.448 * *$ & $0.480 * *$ & $0.451 * *$ & $0.491 * *$ & $0.435 * *$ \\
\hline & $(0.211)$ & $(0.201)$ & $(0.199)$ & $(0.198)$ & $(0.198)$ & $(0.210)$ & $(0.215)$ \\
\hline $\begin{array}{l}\text { UB net replacement rate } \\
\text { (average over } 60 \text { months) }\end{array}$ & $\begin{array}{l}0.003 * \\
(0.003)\end{array}$ & $\begin{array}{l}0.004^{*} \\
(0.002)\end{array}$ & $\begin{array}{l}0.004^{*} \\
(0.002)\end{array}$ & $\begin{array}{l}0.005^{* *} \\
(0.002)\end{array}$ & $\begin{array}{l}0.006 * * \\
(0.002)\end{array}$ & $\begin{array}{l}0.004 \\
(0.002)\end{array}$ & $\begin{array}{l}0.005 * * \\
(0.002)\end{array}$ \\
\hline \multicolumn{8}{|c|}{ Interaction terms with lagged dependent variable } \\
\hline \multirow[t]{2}{*}{ Cost to employer hours not worked } & 0.003 & & & & & & -0.002 \\
\hline & $(0.004)$ & & & & & & $(0.004)$ \\
\hline \multirow[t]{2}{*}{ STW net replacement rate } & & 0.000 & & & & & 0.004 \\
\hline & & $(0.004)$ & & & & & $(0,006)$ \\
\hline \multirow[t]{2}{*}{ Maximum duration } & & & -0.001 & & & & -0.001 \\
\hline & & & $(0.002)$ & & & & $(0001)$ \\
\hline \multirow[t]{2}{*}{ Strictness of eligibility criteria } & & & & 0.141 & & & 0.342 \\
\hline & & & & $(0.171)$ & & & $(0.256)$ \\
\hline \multirow[t]{2}{*}{ Strictness of conditionality criteria } & & & & & -0.440 & & 0.214 \\
\hline & & & & & $(0.413)$ & & $(0.536)$ \\
\hline $\begin{array}{l}\text { Difference of maximum } \\
\text { and minimum permissible \% } \\
\text { reduction in weekly hours }\end{array}$ & & & & & & $\begin{array}{l}0.598^{*} \\
(0.310)\end{array}$ & $\begin{array}{l}0.339 \\
(0.426)\end{array}$ \\
\hline
\end{tabular}


Table 2 The role of institutional characteristics for the use of STW ${ }^{a .}$ (Continued)

Interaction terms with output

\begin{tabular}{|c|c|}
\hline $\begin{array}{l}\text { Cost to employer for hours } \\
\text { not worked }\end{array}$ & $\begin{array}{l}-0.123 * \\
(0.065)\end{array}$ \\
\hline STW net replacement rate & \\
\hline
\end{tabular}

Maximum duration

0.066)

$-0.076$

$(0.072)$

$-0.077$

$(0.061)$

$-0.021$

$(0.030)$

$(0.020)$

Strictness of eligibility criteria

$-8.083 * *$

$-9.372 * *$

(4.461)

Strictness of conditionality criteria

(3.607)

Difference of maximum

and minimum permissible $\%$

reduction in weekly hours

\section{Number of countries}

Number of observations

R-squared

$306 \quad 306$

8
306
0.953

18
306
0.953

18

$15.560 * *$

12.840

***,**, *: Statistically significant at the $1 \%, 5 \%$ and $10 \%$ level, respectively.

$0.953 \quad 0.953$

(7.998)

Robust standard errors in brackets. Regressions include country time quarter dummies and year dummies.

a) The use of STW, the dependent variable of the regression analysis, is defined as the number of participants in STW over total dependent employment. Source: Authors' estimates. 
we simply concentrate on the short-term relationship between average hours, output and STW that results when $\phi=0$.

\subsection{Controlling for selection}

As noted by Hijzen and Venn (2010), simple OLS estimates of the models above may yield misleading results. First, estimates of these models may be biased because the output elasticity may not be just a function of STW but also of other institutional settings. For example, OECD (2010) argues that STW has tended to develop in many countries as a way to compensate firms for the negative impact of employment protection on external flexibility by promoting internal flexibility. When STW is positively correlated with institutional factors that reduce the output elasticity of labour demand, this is likely to lead to an overestimate of the impact of STW on preserving jobs. Assuming that the role of these other institutional factors does not vary over time, Hijzen and Venn (2010) propose a difference-in-differences approach that focuses on the difference in the output elasticity of labour demand before and during the crisis across countries. Boeri and Brucker (2011) do not control for the role of unobservable factors, but directly control for the main institutional factors that are likely to affect the elasticity of labour demand and are correlated with the use of STW. This paper adopts a similar approach by including indicators of the stringency of employment protection and the generosity of unemployment insurance as independent variables as well as interacted with the change in log output.

Second, STW may be endogenous with respect to the outcome of variable of interest to the role of macro-economic information that affects both employment and STW, but is not captured by the change in output. In the case of employment, not accounting for endogeneity is likely to lead to the underestimation of the impact of STW. Hijzen and Venn (2010) keep the level of STW during the crisis constant to reduce endogeneity concerns, but this does not solve the problem entirely. Their estimates of the number of jobs saved are, therefore, likely to be on the conservative side. This paper follows the approach used in Boeri and Brucker (2011) who address the problem of endogeneity through the use of an instrumental variable for STW based on the number of years for which a scheme has been in existence. Since it takes time to learn about the existence and operation of labour market programmes such as STW, take-up is likely to increase with the time a programme has been in existence. This is indeed confirmed by the evidence in Section 2. To the extent that the macro-economic conditions that might have given rise to the establishment of the programme are unrelated to the macro-economic conditions that led to the surge in STW during the global financial crisis, this provides a valid instrument for STW. As this condition is clearly not valid for programmes that were established during the global financial crisis, countries that did so were excluded from the IV estimations.

\section{Data}

For the purposes of this paper, the dataset constructed by Hijzen and Venn (2010) was extended to cover a larger number of countries and to include a larger part of the recent crisis period. This increased the number of countries covered from 19 to 23 and the data period from 2004 Q1-2009Q4 to 2004 Q1-2010 Q4. The use of five additional quarters over a period in which the use of STW was relatively high is considered to be an important contribution of this paper. Of the 23 countries that are included in the 
analysis, 13 countries operated a scheme already before the start of the global financial crisis, five introduced a new scheme in response to the crisis and five countries never operated a STW scheme. Since national data on the use of STW are not readily comparable across countries significant efforts were made to enhance cross-country comparability in terms of the kind of programmes that are covered and the way take-up is recorded across countries. Take-up is measured in this paper as the number of participants across months as a share of dependent employment. Note that it would have been preferable to measure take-up in terms of full-time equivalents (FTE). However, this requires information on the reduction in working time among STW participants which is not available for the majority of countries. For further details on the construction of this dataset, see Hijzen and Venn (2010) and the Additional file 1.

Table 3 provides an overview of the use of STW before, during and after the crisis for countries for which comparable data are available ${ }^{8}$. At the onset of the crisis in the fourth quarter of 2007, take-up of STW was negligible in most countries. An important exception is Belgium where take-up amounted to about $3 \%$ of dependent employment. Finland, France, and Italy also had moderate levels of take-up, but well below 1\% of employment. During the crisis, take-up surged dramatically. At its peak, it amounted to over 7\% in Belgium, around 4 to 5\% in Germany and Japan, 2.5\% in Italy, and around 1 to $2 \%$ in Austria, Czech Republic, Finland, France, Ireland, the Netherlands, and Slovak Republics. In the other countries, it remained below $1 \%$. In all countries, take-up has declined substantially since reaching its peak. Only in Belgium, Italy and Japan did take-up exceed 1\% of employment as of 2010 Q4.

The rise in take-up is closely related to the deterioration in business conditions during the crisis and their subsequent recovery, although there are considerable differences in the extent to which take-up responded to changes in GDP. Take-up increased most strongly in response to the crisis in Belgium, where take-up rose by more than one percentage point for each percent decline in GDP. The responsiveness of take-up was also strong in countries such as Germany and Japan, where it increased by more than half a percentage point for each percent decline in GDP. By contrast, responsiveness was very low in Denmark, Ireland, Poland and Portugal. During the initial recovery, the responsiveness of take-up to improvements in GDP was similar to that during the crisis in most countries. This suggests that concerns about the difficulty of scaling down STW schemes in the recovery may not be very important.

The core database on labour market outcomes and output is derived from Eurostat's Quarterly National Accounts, the European Labour Force Survey and various national sources for the non-European countries. Output is defined in real terms in national currency using the GDP deflator.

\section{Econometric results}

Sections 5.1 and 5.2 present the discussion of the static and the dynamic results respectively. The discussion focuses largely on the labour market outcomes for permanent workers in relation to their employment, average hours worked and total hours. This reflects previous results by Hijzen and Venn (2010) which showed that the positive effects of STW are largely limited to permanent workers. The discussion of the static results in Section 5.1 mainly serves to get a first indication of the possible role of STW on labour market outcomes and to motivate the dynamic analysis in Section 5.2. 
The discussion of the static results is kept as brief as possible, while the dynamic results are discussed in more detail. Section 5.3 discusses dynamic results in relation to the UB recipiency rate and the harmonised unemployment rate.

\subsection{Static results on employment and hours}

Panel A of Table 4 reports the results from the static model based on the contemporaneous relationship between labour market outcomes, output and the use of STW for three different specifications: OLS without institutional controls (column 1); OLS with institutional controls (column 2); IV with controls (column 3). The results in column 1 of Panel A suggest that STW has no or a positive effect on the output elasticity of permanent employment and a positive effect on the output elasticity of working time for permanent workers. Thus, the results suggest that, as expected, STW increases the flexibility of average hours worked, but do not provide evidence that the reduction in working time associated with the use of STW in recessions mitigates the employment response to negative output shocks. These results do not change much when controlling for selection effects by including measures for the level of employment protection and the generosity of unemployment benefits or by instrumenting STW using the age of the programme.

However, as shown in Panels B and C of Table 4, the results change markedly for employment and average hours worked when using the first or the second lags of output changes and take-up instead of their contemporaneous values. For example, the interaction term between take-up and the change in output is consistently negative and statistically significant in the case of employment, in line with findings in previous studies. Moreover, the interaction between take-up and the change in output in the case of average hours is positive when using the first lag (Panel B), as in Panel A, but becomes negative and statistically significant when using the second lag (Panel C). Importantly, these results suggest that the impact of STW on the output elasticity of employment only materialises after some time, while the impact of STW on average hours worked tends to be immediate.

These differences arise largely because employment only responds slowly to output shocks, while average hours respond quickly, but tend to revert to their optimal long-term values relatively soon. This is consistent with a model in which adjusting employment is relatively costly, while adjusting average hours does not involve a fixed adjustment, but may affect variable costs (Bils, 1987; Cabellero et al., 1997). This implies that it is optimal for firms to adjust to temporary and relatively short-lived shocks by adjusting average hours and to more persistent shocks by adjusting employment. This is consistent with results in Table 4 that suggest that employment responds more strongly to output shocks that occurred with two lags than to contemporaneous shocks and average hours respond positively to contemporaneous output changes and negatively to lagged output changes.

The sensitivity of the static results to the assumed inter-temporal relationship between labour market outcomes, output and take-up highlights the importance of modelling the dynamics of employment and hours with respect to output in a more detailed manner. This is done in the next sub-section.

\subsection{Dynamic results on employment and hours}

The dynamic results are reported in Table 5. The coefficients in relation to the change in output summarise the average impact of a $1 \%$ increase in output on the labour market outcome of interest in the absence of STW schemes. As one would expect, the 
Table 3 The use of short-time work during the global financial crisis

\begin{tabular}{|c|c|c|c|c|c|c|c|}
\hline & \multicolumn{3}{|c|}{ Short-time work take-up rate } & \multicolumn{2}{|c|}{ Change in the take-up rate } & \multirow{2}{*}{\multicolumn{2}{|c|}{$\begin{array}{c}\text { Ratio of the change in the monthly takeup } \\
\text { rate to the change in GDP } \\
\text { Percentage points }\end{array}$}} \\
\hline & \multicolumn{3}{|c|}{ Percentage of dependent employment } & \multicolumn{2}{|c|}{ Percentage of dependent employment } & & \\
\hline & $2007 Q^{a}$ & Peak in STW takeup & 2010 Q4 & $\begin{array}{l}2007 \text { Q4 to peak } \\
\text { in STW takeup }\end{array}$ & $\begin{array}{l}\text { Peak in STW takeup } \\
\text { to } 2010 \text { Q4 }\end{array}$ & $\begin{array}{l}2007 \text { Q4 to peak } \\
\text { in STW takeup }\end{array}$ & $\begin{array}{c}\text { Peak in STW takeup } \\
\text { k } 2010 \text { Q4 }\end{array}$ \\
\hline Austria & 0.00 & 1.16 & 015 & 1.16 & -1.01 & -0.35 & -0.24 \\
\hline Belgium & 3.03 & 7.45 & 3.79 & 4.43 & -3.66 & -1.38 & -0.91 \\
\hline Canada & 0.01 & 0.42 & 0.12 & 0.41 & -0.30 & -0.13 & -0.07 \\
\hline Czech Republic & 0.00 & 1.96 & 0.25 & 1.96 & -1.71 & -0.46 & -0.39 \\
\hline Denmark & 0.00 & 0.48 &. & 0.48 & .. & -0.06 &. \\
\hline Finland & 0.35 & 1.87 & 0.99 & 1.52 & -0.88 & -0.18 & -0.16 \\
\hline France & 0.20 & 1.11 & 0.77 & 0.91 & -0.34 & -0.26 & -0.15 \\
\hline Germany & 0.06 & 4.15 & 0.55 & 4.09 & -3.60 & -0.74 & -0.67 \\
\hline Hungary & 0.00 & 0.86 & 0.05 & 0.86 & -0.81 & -0.12 & -0.30 \\
\hline Ireland & 0.00 & 1.17 & 0.84 & 1.17 & -0.34 & -0.10 & 0.22 \\
\hline Italy & 0.41 & 2.49 & 1.78 & 2.07 & -0.70 & -0.35 & -0.45 \\
\hline Japan & 0.00 & 4.59 & 1.33 & 4.59 & -3.26 & -0.64 & -0.62 \\
\hline Netherlands & 0.00 & 1.11 & 0.15 & 1.11 & -0.96 & -0.31 & -0.40 \\
\hline Norway & 0.07 & 0.79 & 0.36 & 0.72 & -0.44 & -0.29 & -0.58 \\
\hline Poland & 0.00 & 0.03 & 0.00 & 0.03 & -0.03 & 0.00 & -0.01 \\
\hline Portugal & 0.01 & 0.36 & 0.17 & 0.35 & -0.19 & -0.11 & -0.20 \\
\hline Slovak Republic & 0.00 & 1.37 & 0.08 & 1.37 & -1.29 & -0.41 & -0.38 \\
\hline Spain & 0.00 & 0.79 & 0.47 & 0.79 & -0.32 & -0.18 & -0.45 \\
\hline
\end{tabular}

Not available.

a) 2008 Q1 for Spain.

Source: Authors' calculations based on administrative data provided by the national authorities and OECD Main Economic Indicators Database. 
proportional impact of output changes on total hours worked approximately equals the sum of its proportional impact on employment and working time ${ }^{9}$. The bulk of the contemporaneous response in total hours is driven by changes in working time. However, the impact of average hours is reversed relatively quickly, while the full impact on employment only materialises slowly over time. The negative impact of a $1 \%$ reduction in output on employment equals about $0.1 \%$ at time $t$, an additional 0.1 at $t+1$ and an additional to $0.3 \%$ at time $t+2$.

In principle, STW schemes could affect labour demand directly and indirectly by affecting the way output shocks are transmitted to labour demand. The results, however, generally provide little evidence for any direct effects of STW. Only when the endogeneity of take-up is taken into account is there some evidence that STW reduces the contemporaneous growth rate of average hours worked independently of output changes. This is, perhaps, not surprising since STW is a programme that is explicitly designed to reduce working time. More interestingly, there is some indication that STW take-up slows employment growth in the future. However, this effect is economically very small and only in one specification statistically significant at the $10 \%$ level. In principle, the direct negative effect of STW on employment could reflect its adverse impact on the reallocation of workers between more and less productive firms ${ }^{10}$. Concerns about the potential adverse effects of STW on job reallocation have motivated recommendations by the OECD that STW should only be used in the context of economic downturns and that its use should be strictly temporary (OECD, 2009, 2010).

The indirect effects of STW on the responsiveness of labour market outcomes to output shocks are potentially important. STW schemes increase the contemporaneous elasticity of average hours worked for permanent workers with respect to output shocks. The immediate impact of STW on average hours worked of permanent workers is sizeable: a one percentage point increase in the STW take-up rate increases the contemporaneous output elasticity of average hours worked by about 0.25 (column 1), or about 10 hours in the case of full-time workers with a regular working week of 40 hours $^{11}$. STW does not have an immediate impact on the employment elasticity of permanent workers, but exerts a significant impact on the output elasticity of employment with some lag. More specifically, the estimates suggest that a 1 percentage point increase in the take-up rate of STW reduces the employment elasticity of permanent workers by 0.09 after two quarters.

The results in Table 5 are robust to a variety of wide different specifications. In particular, the results are qualitatively similar when: countries without STW schemes are excluded from the sample; additional variables are included to control for the role of employment protection and the generosity of unemployment insurance and their impact on the responsiveness of labour inputs to output shocks; the potential endogeneity of STW is addressed by instrumenting the STW take-up rate by the number of years since the introduction of STW as suggested by Boeri and Brucker (2011).

Column (2) of Table 5 reports the results that include indicators for the stringency of employment protection and the generosity of unemployment insurance independently as well as in interaction with the change in output. These results suggest that employment protection, similar to STW, reduces the output elasticity of permanent employment. The generosity of unemployment insurance, if anything, increases the elasticity of employment with respect to output, suggesting that more generous unemployment benefits increase the risk of job loss. The results with respect to STW are essentially unchanged. 
Table 4 Static results on the impact of STW on the labour market outcomes of permanent workers

\begin{tabular}{|c|c|c|c|c|c|c|c|c|c|}
\hline & \multicolumn{3}{|c|}{ Change in employment } & \multicolumn{3}{|c|}{ Change in average hours worked } & \multicolumn{3}{|c|}{ Change in total hours worked } \\
\hline & Model 1 & Model 2 & Model 3 & Model 1 & Model 2 & Model 3 & Model 1 & Model 2 & Model 3 \\
\hline & OLS & $\begin{array}{l}\text { OLS with } \\
\text { institutions }\end{array}$ & $\begin{array}{l}\text { IV with } \\
\text { institutions }\end{array}$ & OLS & $\begin{array}{l}\text { OLS with } \\
\text { institutions }\end{array}$ & $\begin{array}{l}\text { IV with } \\
\text { institutions }\end{array}$ & OLS & $\begin{array}{l}\text { OLS with } \\
\text { institutions }\end{array}$ & $\begin{array}{l}\text { IV with } \\
\text { institutions }\end{array}$ \\
\hline \multicolumn{10}{|c|}{ A. Contemporaneous output shocks and take-up rate } \\
\hline \multirow[t]{2}{*}{ Output growth } & $0.194 * * *$ & $0.319 * * *$ & -6.031 & $0.258^{* * *}$ & 0.208 & -6.977 & $0.454 * * *$ & 0.452 & -13.009 \\
\hline & $(0.050)$ & $(0.101)$ & $(5.291)$ & $(0.097)$ & $(0.256)$ & $(6.333)$ & $(0.110)$ & $(0.288)$ & $(9.050)$ \\
\hline \multirow[t]{2}{*}{ STW take-up rate } & 0.000 & 0.000 & 0.276 & 0.002 & 0.002 & 0.317 & 0.002 & 0.002 & 0.593 \\
\hline & $(0.001)$ & $(0.001)$ & $(0.236)$ & $(0.002)$ & $(0.002)$ & $(0.278)$ & $(0.002)$ & $(0.002)$ & $(0.400)$ \\
\hline \multirow[t]{2}{*}{ Output growth times STW take-up rate } & 0.002 & 0.022 & $0.080 *$ & $0.168 * *$ & $0.146 *$ & 0.125 & $0.172 * *$ & $0.164 * *$ & $0.206 *$ \\
\hline & $(0.033)$ & $(0.035)$ & $(0.045)$ & $(0.069)$ & $(0.077)$ & $(0.107)$ & $(0.073)$ & $(0.081)$ & $(0.110)$ \\
\hline \multirow[t]{2}{*}{ Overall strictness of employment protection } & & $-0.009 * *$ & -0.357 & & -0.001 & -0.405 & & -0.009 & -0.762 \\
\hline & & $(0.004)$ & $(0.302)$ & & $(0.013)$ & $(0.357)$ & & $(0.013)$ & $(0.513)$ \\
\hline \multirow[t]{2}{*}{ UB net replacement rate (averageover 60 months) } & & $0.000 * *$ & -0.005 & & 0.000 & -0.006 & & 0.000 & -0.011 \\
\hline & & $(0.000)$ & $(0.004)$ & & $(0.000)$ & $(0.005)$ & & $(0.000)$ & $(0.007)$ \\
\hline \multirow{2}{*}{$\begin{array}{l}\text { Output growth times overall strictness of } \\
\text { employment protection }\end{array}$} & & -0.062 & 1.192 & & 0.037 & 1.669 & & 0.013 & 2.861 \\
\hline & & $(0.055)$ & $(1.149)$ & & $(0.130)$ & $(1.401)$ & & $(0.144)$ & $(1.984)$ \\
\hline \multirow{2}{*}{$\begin{array}{l}\text { Output growth times UB net replacement rate } \\
\text { (average over 60) }\end{array}$} & & -0.001 & 0.059 & & 0001 & 0.066 & & 0.000 & 0.125 \\
\hline & & $(0.002)$ & $(0.048)$ & & $(0.004)$ & $(0.058)$ & & $(0.005)$ & $(0.082)$ \\
\hline Number of countries & 23 & 23 & 13 & 23 & 23 & 13 & 23 & 23 & 13 \\
\hline Number of observations & 633 & 617 & 354 & 633 & 617 & 354 & 633 & 617 & 354 \\
\hline R-squared & 0.39 & 0.39 & 0.34 & 0.94 & 0.94 & 0.93 & 0.92 & 0.92 & 0.91 \\
\hline
\end{tabular}


Table 4 Static results on the impact of STW on the labour market outcomes of permanent workers (Continued)

\begin{tabular}{|c|c|c|c|c|c|c|c|c|c|}
\hline \multicolumn{10}{|c|}{ B. Output shocks and take-up rate lagged one quarter } \\
\hline Output growth & $0.160 * *$ & 0.097 & -0.052 & -0.151 & -0.207 & $-1.258^{* * *}$ & 0.008 & -0.226 & $-1.310 * * *$ \\
\hline & $(0.065)$ & $(0.105)$ & $(0.217)$ & $(0.105)$ & $(0.280)$ & $(0.443)$ & $(0.129)$ & $(0.305)$ & $(0.496)$ \\
\hline \multirow[t]{2}{*}{ STW take-up rate } & 0.001 & 0.001 & 0.004 & $0.005 * *$ & $0.005^{* *}$ & $0.040 * * *$ & $0.005 * *$ & $0.006 * *$ & $0.044 * * *$ \\
\hline & $(0.001)$ & $(0.001)$ & $(0.003)$ & $(0.002)$ & $(0.002)$ & $(0.007)$ & $(0.002)$ & $(0.002)$ & $(0.007)$ \\
\hline \multirow[t]{2}{*}{ Output growth times STW take-up rate } & $-0.083^{* *}$ & -0.063 & -0.057 & 0.070 & 0.089 & $0.305 * * *$ & -0.009 & 0.023 & $0.249^{*}$ \\
\hline & $(0.038)$ & $(0.041)$ & $(0.051)$ & $(0.063)$ & $(0.071)$ & $(0.117)$ & $(0.081)$ & $(0.085)$ & $(0.139)$ \\
\hline \multirow[t]{2}{*}{ Overall strictness of employment protection } & & $-0.009 * *$ & -0.009 & & -0.018 & $-0.060 * * *$ & & $-0.026^{*}$ & $-0.068 * * *$ \\
\hline & & $(0.004)$ & $(0.006)$ & & $(0.015)$ & $(0.016)$ & & $(0.015)$ & $(0.017)$ \\
\hline \multirow[t]{2}{*}{ UB net replacement rate (averageover 60 months) } & & $0.000 * *$ & $0.000 * *$ & & 0.000 & $-0.001 *$ & & 0.000 & $-0.001 * *$ \\
\hline & & $(0.000)$ & $(0.000)$ & & $(0.000)$ & $(0.000)$ & & $(0.000)$ & $(0.000)$ \\
\hline \multirow{2}{*}{$\begin{array}{l}\text { Output growth times overall strictness of } \\
\text { employment protection }\end{array}$} & & 0.044 & 0.030 & & 0.085 & 0.043 & & 0.184 & 0.073 \\
\hline & & $(0.064)$ & $(0.108)$ & & $(0.143)$ & $(0.214)$ & & $(0.151)$ & $(0.218)$ \\
\hline \multirow{2}{*}{$\begin{array}{l}\text { Output growth times UB net replacement rate } \\
\text { (average over } 60 \text { ) }\end{array}$} & & -0.002 & 0 & & -0.004 & $0.009^{*}$ & & -0.005 & 0.01 \\
\hline & & $(0.003)$ & $(0.003)$ & & $(0.005)$ & $(0.005)$ & & $(0.005)$ & $(0.006)$ \\
\hline Number of countries & 23 & 23 & 13 & 23 & 23 & 13 & 23 & 23 & 13 \\
\hline Number of observations & 614 & 598 & 344 & 614 & 598 & 344 & 614 & 598 & 344 \\
\hline R-squared & 0.45 & 0.48 & 0.42 & 0.94 & 0.94 & 0.94 & 0.93 & 0.93 & 0.93 \\
\hline
\end{tabular}


Table 4 Static results on the impact of STW on the labour market outcomes of permanent workers (Continued)

\begin{tabular}{|c|c|c|c|c|c|c|c|c|c|}
\hline \multicolumn{10}{|c|}{ C. Output shocks and take-up rate lagged two quarters } \\
\hline Output growth & $0.290 * * *$ & $0.212 * *$ & 0.260 & -0.121 & -0.338 & -0.400 & 0.170 & -0.230 & -0.140 \\
\hline & $(0.046)$ & $(0.098)$ & $(0.177)$ & $(0.098)$ & $(0.270)$ & $(0.403)$ & $(0.113)$ & $(0.293)$ & $(0.441)$ \\
\hline \multirow[t]{2}{*}{ STW take-up rate } & 0.000 & 0.000 & -0.001 & $0.003 *$ & $0.003^{*}$ & $0.016^{* * *}$ & 0.003 & 0.003 & $0.015^{* *}$ \\
\hline & $(0.001)$ & $(0.001)$ & $(0.003)$ & $(0.002)$ & $(0.002)$ & $(0.006)$ & $(0.002)$ & $(0.002)$ & $(0.006)$ \\
\hline \multirow[t]{2}{*}{ Output growth times STW take-up rate } & $-0.133 * * *$ & $-0.134 * * *$ & $-0.139^{* * *}$ & -0.134 * & $-0.157 * *$ & $-0.218 * *$ & $-0.262 * * *$ & $-0.293 * * *$ & $-0.357 * * *$ \\
\hline & $(0.038)$ & $(0.039)$ & $(0.047)$ & $(0.070)$ & $(0.076)$ & $(0.101)$ & $(0.080)$ & $(0.086)$ & $(0.106)$ \\
\hline \multirow[t]{2}{*}{ Overall strictness of employment protection } & & $-0.008 *$ & 0.000 & & -0.002 & -0.015 & & -0.010 & -0.015 \\
\hline & & $(0.005)$ & $(0.006)$ & & $(0.015)$ & $(0.017)$ & & $(0.015)$ & $(0.017)$ \\
\hline \multirow[t]{2}{*}{ UB net replacement rate (averageover 60 months) } & & $0.000 *$ & 0.000 & & 0.000 & 0.000 & & 0.000 & 0.000 \\
\hline & & $(0.000)$ & $(0.000)$ & & $(0.000)$ & $(0.000)$ & & $(0.000)$ & $(0.000)$ \\
\hline \multirow{2}{*}{$\begin{array}{l}\text { Output growth times overall strictness of } \\
\text { employment protection }\end{array}$} & & -0.011 & $-0.152 * *$ & & 0.004 & -0.023 & & 0.044 & -0.175 \\
\hline & & $(0.047)$ & $(0.074)$ & & $(0.126)$ & $(0.209)$ & & $(0.138)$ & $(0.218)$ \\
\hline \multirow{2}{*}{$\begin{array}{l}\text { Output growth times UB net replacement rate } \\
\text { (average over } 60\end{array}$} & & 0.002 & $0.005 * *$ & & 0.006 & 0.008 & & $0.009^{* *}$ & $0.014^{* *}$ \\
\hline & & $(0.002)$ & $(0.003)$ & & $(0.004)$ & $(0.005)$ & & $(0.004)$ & $(0.006)$ \\
\hline Number of countries & 23 & 23 & 13 & 23 & 23 & 13 & 23 & 23 & 13 \\
\hline Number of observations & 593 & 577 & 333 & 593 & 577 & 333 & 593 & 577 & 333 \\
\hline R-squared & 0.48 & 0.51 & 0.46 & 0.94 & 0.94 & 0.94 & 0.932 & 0.93 & 0.93 \\
\hline
\end{tabular}

$* * *, * * *$ : Statistically significant at the $1 \%, 5 \%$ and $10 \%$ level, respectively.

Robust standard errors in brackets. Regressions include country time quarter dummies and year dummies.

a) The use of STW, the dependent variable of the regression analysis, is defined as the number of participants in STW over total dependent employment.

Source: Authors' estimates. 
Column (3) of Table 5 reports the results that are obtained when, in addition to controlling for the independent effect of employment protection and unemployment insurance, the STW take-up rate is instrumented by the number of years the STW programme has been operational. As this is only valid instrument for countries that had a STW schemes in place before the start of the crisis, countries without STW schemes or countries that established such a scheme in 2008 or later are excluded from the estimation sample. Since the endogeneity of STW with respect to labour market outcomes is likely to underestimate the impact of STW on the output elasticity of employment, one would expect its impact to become stronger after instrumenting. This is not observed in Table 5. The impact of STW on the employment elasticity becomes, if anything, somewhat smaller. This most likely reflects the change in the country sample with respect to column (2).

\subsection{Unemployment results}

Two different measures of the unemployment rate are used: i) UB recipiency rate (ratio of UB recipients to the labour force); ii) the harmonised unemployment rate (ratio of unemployed jobseekers to the labour force). In order to facilitate the interpretation of the coefficients STW is now expressed in terms of the labour force instead of dependent employment as before. The unemployment results are of major policy interest for two reasons. First, they provide a direct indication of the effectiveness of STW in keeping unemployment down, a key objective of STW schemes. Second, they can help to provide an indication of the fiscal costs and benefits associated with STW. An easy way to get a sense of this is to compare expenditures in the context of STW schemes with expenditures savings due to the role of STW for the number of unemployment benefit recipients. In order to see how the unemployment results may shed light on this, it is useful to phrase some informal predictions in relation to the coefficients on the interaction terms of output growth and take-up.

When all jobs subject to STW would be suppressed in the absence of STW and all job losers would become unemployed, one would expect the sum of the coefficients on the interaction terms between output growth and take-up to approach one. However, this is unlikely to be the case in practice for several reasons. First, STW is a form of worksharing and, consequently, not all jobs subject to STW are at risk. It is more appropriate, therefore, to focus on the full-time equivalent of the number of STW participants. Assuming an average reduction in working time of about $10 \%$, as suggested by Hijzen and Venn (2010), one would expect the sum of the coefficients on the interaction terms between output growth and take-up to approach 0.25 . Second, not all jobs supported by STW, even when expressed in full-time equivalents, might be suppressed in the absence of STW due to the role of deadweight effects. Third, not all workers that would have lost their job in the absence of STW would have become unemployed. Some might have found another job quickly, whereas others might have decided to leave the labour force. Assuming that the generosity of STW and unemployment benefits is similar as well as the duration of STW and unemployment, one would expect the fiscal balance associated with STW to be negative. While the first assumption seems reasonable (see Hijzen and Venn, 2010), this is less obvious for the second. The fiscal balance of STW may turn positive if the expected duration of unemployment exceeds that of STW.

The unemployment results reported in Table 6 generally mirror those with respect to permanent employment. STW has a tendency to mitigate the unemployment impact of 
Table 5 Dynamic results on the impact of STW on the labour market outcomes of (Cont.)

\begin{tabular}{|c|c|c|c|c|c|c|c|c|c|c|}
\hline & & \multicolumn{3}{|c|}{ Change in employment } & \multicolumn{3}{|c|}{ Change in average hours worked } & \multicolumn{3}{|c|}{ Change in total hours worked } \\
\hline & & $\begin{array}{l}\text { Model 1: } \\
\text { OLS }\end{array}$ & $\begin{array}{c}\text { Model 2: } \\
\text { OLS with institution }\end{array}$ & $\begin{array}{c}\text { Model 3: } \\
\text { IV with institution }\end{array}$ & $\begin{array}{l}\text { Model 1: } \\
\text { OLS }\end{array}$ & $\begin{array}{c}\text { Model 2: } \\
\text { OLS with institution }\end{array}$ & $\begin{array}{c}\text { Model 3: } \\
\text { IV with institution }\end{array}$ & $\begin{array}{l}\text { Model 1: } \\
\text { OLS }\end{array}$ & $\begin{array}{c}\text { Model 2: } \\
\text { OLS with institution }\end{array}$ & $\begin{array}{c}\text { Model 3: } \\
\text { IV with institution }\end{array}$ \\
\hline \multirow{2}{*}{$\begin{array}{l}\text { Lagged dependent } \\
\text { variable in level }\end{array}$} & & $-0.060 * *$ & $-0.087^{* * *}$ & $-0.142^{* *}$ & & & & $-0.248 * * *$ & $-0.300 * * *$ & $-0.372 * * *$ \\
\hline & & $(0.026)$ & $(0.030)$ & $(0.057)$ & & & & $(0.046)$ & $(0.052)$ & $(0.081)$ \\
\hline \multirow[t]{2}{*}{ Output } & & 0.015 & 0.014 & $0.093^{*}$ & & & & $0.112 * * *$ & $0.098 * * *$ & $0.364^{* * *}$ \\
\hline & & $(0.016)$ & $(0.016)$ & $(0.052)$ & & & & $(0.032)$ & $(0.034)$ & $(0.093)$ \\
\hline \multirow[t]{6}{*}{ Output growth } & $\mathrm{t}$ & $0.125^{* * *}$ & $0.215^{* *}$ & 0.381 & $0.321 * * *$ & 0.442 & $1.946 * * *$ & $0.392 * * *$ & $0.777^{* *}$ & $4.224 * * *$ \\
\hline & & $(0.048)$ & $(0.108)$ & $(0.387)$ & $(0.108)$ & $(0.294)$ & $(0.655)$ & $(0.111)$ & $(0.302)$ & $(0.912)$ \\
\hline & $\mathrm{t}-1$ & $0.100 *$ & 0.140 & 0.151 & $-0.216 * *$ & -0.333 & $-1.394 * *$ & -0.082 & -0.128 & $-0.970 *$ \\
\hline & & $(0.059)$ & $(0.122)$ & $(0.234)$ & $(0.107)$ & $(0.347)$ & $(0.566)$ & $(0.102)$ & $(0.341)$ & $(0.549)$ \\
\hline & $t-2$ & $0.271^{* * *}$ & $0.227^{* *}$ & $0.301 *$ & -0.094 & -0.192 & 0.281 & $0.234^{* *}$ & 0.081 & 0.439 \\
\hline & & $(0.045)$ & $(0.100)$ & $(0.177)$ & $(0.103)$ & $(0.338)$ & $(0.507)$ & $(0.106)$ & $(0.308)$ & $(0.504)$ \\
\hline \multirow[t]{6}{*}{ STW take-up rate } & $t$ & 0.001 & 0.001 & -0.016 & 0.008 & 0.006 & $-0.090^{* * *}$ & 0.008 & 0.005 & $-0.177^{* * *}$ \\
\hline & & $(0.002)$ & $(0.002)$ & $(0.018)$ & $(0.005)$ & $(0.005)$ & $(0.018)$ & $(0.005)$ & $(0.005)$ & $(0.037)$ \\
\hline & $t-1$ & 0.000 & 0.001 & 0.005 & -0.008 & -0.006 & $0.036^{* * *}$ & -0.008 & -0.005 & $0.031 * * *$ \\
\hline & & $(0.003)$ & $(0.003)$ & $(0.004)$ & $(0.008)$ & $(0.008)$ & $(0.010)$ & $(0.008)$ & $(0.007)$ & $(0.010)$ \\
\hline & $t-2$ & -0.002 & -0.002 & $-0.005^{*}$ & 0.003 & 0.002 & -0.002 & 0.001 & 0.001 & -0.002 \\
\hline & & $(0.003)$ & $(0.003)$ & $(0.003)$ & $(0.004)$ & $(0.004)$ & $(0.009)$ & $(0.005)$ & $(0.005)$ & $(0.009)$ \\
\hline \multirow{6}{*}{$\begin{array}{l}\text { Output growth times } \\
\text { STW take-up rate }\end{array}$} & $t$ & 0.055 & 0.059 & $0.105 *$ & $0.253^{* *}$ & $0.267^{* *}$ & 0.013 & $0.235 * *$ & $0.250 * *$ & 0.067 \\
\hline & & $7(0.043)$ & $(0.042)$ & $(0.053)$ & $(0.102)$ & $(0.109)$ & $(0.117)$ & $(0.103)$ & $(0.100)$ & $(0.113)$ \\
\hline & $t-1$ & -0.053 & -0.057 & $-0.108 * *$ & 0.051 & -0.010 & $0.310 * *$ & 0.011 & -0.043 & 0.187 \\
\hline & & $(0.048)$ & $(0.046)$ & $(0.048)$ & $(0.082)$ & $(0.090)$ & $(0.142)$ & $(0.091)$ & $(0.092)$ & $(0.135)$ \\
\hline & $t-2$ & $-0.090 * *$ & $-0.089 * *$ & $-0.081 *$ & $-0.148 * *$ & -0.129 & $-0.327 * * *$ & $-0.236 * * *$ & $-0.209 * *$ & $-0.314^{* * *}$ \\
\hline & & $(0.036)$ & $(0.037)$ & $(0.041)$ & $(0.072)$ & $(0.081)$ & $(0.103)$ & $(0.074)$ & $(0.082)$ & $(0.095)$ \\
\hline
\end{tabular}


Table 5 Dynamic results on the impact of STW on the labour market outcomes of (Cont.) (Continued)

\begin{tabular}{|c|c|c|c|c|c|c|c|}
\hline \multirow{6}{*}{$\begin{array}{l}\text { Overall strictness of } \\
\text { employment protection }\end{array}$} & \multirow[t]{2}{*}{$\mathrm{t}$} & -0.017 & 0.010 & $0.084^{* * *}$ & $0.145^{* * *}$ & $0.082^{* * *}$ & $0.289 * * *$ \\
\hline & & $(0.012)$ & $(0.027)$ & $(0.029)$ & $(0.049)$ & $(0.027)$ & $(0.064)$ \\
\hline & \multirow[t]{2}{*}{$t-1$} & 0.012 & 0.014 & $-0.202^{* * *}$ & $-0.165^{* *}$ & $-0.171 * * *$ & $-0.135 *$ \\
\hline & & $(0.014)$ & $(0.022)$ & $(0.061)$ & $(0.079)$ & $(0.058)$ & $(0.075)$ \\
\hline & \multirow[t]{2}{*}{$t-2$} & 0.000 & 0.010 & $0.118^{* *}$ & 0.093 & 0.076 & 0.059 \\
\hline & & $(0.009)$ & $(0.017)$ & $(0.053)$ & $(0.068)$ & $(0.051)$ & $(0.061)$ \\
\hline \multirow{6}{*}{$\begin{array}{l}\text { Output growth times } \\
\text { overall strictness of } \\
\text { employment protection }\end{array}$} & \multirow[t]{2}{*}{$\mathrm{t}$} & $-0.099 *$ & $-0.265^{* *}$ & -0.076 & -0.390 & $-0.329 * *$ & $-1.226 * * *$ \\
\hline & & $(0.059)$ & $(0.107)$ & $(0.147)$ & $(0.253)$ & $(0.141)$ & $(0.285)$ \\
\hline & \multirow[t]{2}{*}{$\mathrm{t}-1$} & 0.006 & 0.017 & 0.187 & 0.130 & 0.123 & -0.014 \\
\hline & & $(0.071)$ & $(0.113)$ & $(0.174)$ & $(0.260)$ & $(0.165)$ & $(0.228)$ \\
\hline & \multirow[t]{2}{*}{$t-2$} & -0.056 & $-0.217^{* *}$ & -0.084 & -0.033 & -0.143 & $-0.378 *$ \\
\hline & & $(0.056)$ & $(0.084)$ & $(0.165)$ & $(0.231)$ & $(0.158)$ & $(0.223)$ \\
\hline \multirow{6}{*}{$\begin{array}{l}\text { UB net replacement rate } \\
\text { (average over } 60 \text { months) }\end{array}$} & \multirow[t]{2}{*}{ t } & 0.000 & 0.000 & 0.001 & $0.002 * * *$ & $0.001^{*}$ & $0.004 * * *$ \\
\hline & & $(0.000)$ & $(0.000)$ & $(0.001)$ & $(0.001)$ & $(0.000)$ & $(0.001$ \\
\hline & \multirow[t]{2}{*}{$t-1$} & 0.000 & $-0.001 * *$ & $-0.003 * * *$ & $-0.004^{* * *}$ & $-0.003^{* * *}$ & $-0.004 * * *$ \\
\hline & & $(0.000)$ & $(0.000)$ & $(0.001)$ & $(0.001)$ & $(0.001)$ & $(0.001)$ \\
\hline & \multirow[t]{2}{*}{$t-2$} & 0.000 & 0.000 & $0.002 * * *$ & $0.003 * * *$ & 0.002 ** & $0.002^{* * *}$ \\
\hline & & $(0.000)$ & $(0.000)$ & $(0.001)$ & $(0.001)$ & $(0.001)$ & $(0.001)$ \\
\hline \multirow{6}{*}{$\begin{array}{l}\text { Output growth times UB } \\
\text { net replacement rate } \\
\text { (average over } 60 \text { months) }\end{array}$} & \multirow[t]{2}{*}{ t } & 0.002 & 0.003 & -0.001 & $-0.015^{*}$ & 0.002 & $-0.027^{* * *}$ \\
\hline & & $(0.002)$ & $(0.005)$ & $(0.005)$ & $(0.008)$ & $(0.005)$ & $(0.010)$ \\
\hline & \multirow[t]{2}{*}{$t-1$} & -0.002 & -0.002 & -0.004 & 0.010 & -0.004 & 0.010 \\
\hline & & $(0.002)$ & $(0.003)$ & $(0.005)$ & $(0.006)$ & $(0.004)$ & $(0.006)$ \\
\hline & \multirow[t]{2}{*}{$\mathrm{t}-2$} & $0.003 *$ & $0.007 * * *$ & 0.006 & -0.002 & 0.009 ** & 0.010 \\
\hline & & $(0.002)$ & $(0.002)$ & $(0.005)$ & $(0.006)$ & $(0.004)$ & $(0.006)$ \\
\hline
\end{tabular}


Table 5 Dynamic results on the impact of STW on the labour market outcomes of (Cont.) (Continued)

\begin{tabular}{|c|c|c|c|c|c|c|c|c|c|}
\hline Number of countries & 23 & 23 & 13 & 23 & 23 & 13 & 23 & 23 & 13 \\
\hline Number of observations & 589 & 573 & 330 & 589 & 573 & 330 & 589 & 573 & 330 \\
\hline R-squared & 0.53 & 0.58 & 0.55 & 0.94 & 0.95 & 0.95 & 0.95 & 0.95 & 0.95 \\
\hline
\end{tabular}

Robust standard errors in brackets. Regressions include country time quarter dummies and year dummies.

a) Dependent variables and output in logs.

******, *: Statistically significant at the $1 \%, 5 \%$ and $10 \%$ level, respectively.

Source: Authors' estimates. 
output shocks: the increase in unemployment as a result of a reduction in output tends to be smaller in the context of STW. Moreover, the impact of STW on the elasticity of the unemployment rate with respect to output materialises only with a lag, reflecting the lagged impact of output changes on employment. Thus, STW not only helps to maintain employment in the context of a recession, it also helps to keep unemployment down. The results are qualitatively similar across specifications. Moreover, the cumulative size of the coefficients the interactions terms is consistently much smaller than 0.25 , suggesting that deadweight effects are important or that not all job losers in the absence of STW would become unemployed. However, there is considerable uncertainty about the precise quantitative impact of STW. The impact of STW on the output elasticity of unemployment tends to be considerably more positive when controlling for the endogeneity of STW and when using the harmonised unemployment rate as the dependent variable.

\section{Quantifying the role of STW during the global financial crisis}

In order to get a sense of the quantitative impact of STW schemes, the estimated coefficients reported in column (1) of Table 5 are used to calculate the proportional and absolute impacts of STW for permanent employment since the start of the crisis until 2010 Q4 ${ }^{12}$. Differences across countries are exclusively driven by differences in the evolution of GDP and the STW take-up rate since the start of the crisis. The country results have no bearing on the effectiveness of schemes in different countries beyond affecting the responsiveness of take-up to changes in economic conditions. The results are reported in Figure 1 for Germany, Italy and Japan, three large countries where the use of STW during the global financial crisis was particularly pronounced. The results for all countries are available upon request from the authors. The following insights emerge:

- Short-time work schemes had a significant impact on preserving jobs during the crisis. The largest impact is observed in Germany, Italy and Japan. In Germany, Italy and Japan, the net impact since the start of the crisis attained a peak when permanent employment is estimated to have been, respectively, $2 \%, 0.9 \%$ and $1.1 \%$ higher than what it would have been in the absence of short-time work. This corresponds to about 580.000 jobs in Germany, 130.000 in Italy and 445.000 in Japan.

- However, the same estimates also suggest that the continued use of STW during the recovery exerted a negative influence over the job-content of the recovery. As a result, the net effect on employment has fallen importantly in the recovery and in a few countries even has become negative. In the last quarter of 2010, the net employment impact of STW since the start of the crisis was slightly negative in Germany $(-0.7 \%)$ and Italy $(-0.1 \%)$ and strongly negative in Japan $(-1.5 \%)$.

- The social impact of STW is best measured in terms the cumulative jobs impact of STW, that is, the sum of number of jobs saved in each quarter. We refer to this is that gross impact. The gross impact is positive is substantial and positive in all countries, except Japan. In Germany, the cumulative number of jobs saved each quarter amounts to almost 1.2 million, while it amounts to 460.000 in Italy. Japan represents an exception. The social impact was negative by about 15.000at the end of 2010 . The analysis presented here assumes that the impact of STW is symmetric during downturns and recoveries. There may be various reasons why this is not true in practice. For example, Hijzen and Venn (2010) emphasize that the balance of costs of 
benefits is likely to vary over the cycle, turning more negative in recoveries. There may also be composition effects that render the impact of STW asymmetric over the cycle. For example, the use of STW may be relatively widespread in the context of an economic downturn when many firms face financial difficulties, but is likely to be limited to firms facing adverse business conditions in the recovery when most firms are growing ${ }^{13}$. Additional analysis that allows for different effects of STW in recessions and expansions does not suggest this is an important issue in practice. Hence, allowing for asymmetries would not qualitatively change the results presented here.

\section{Simulation results}

In order to more fully appreciate the implications of the results presented in Table 5, it is useful to compare the evolution of employment, total hours and working time under different assumptions about the persistence of the shock and the use of STW. Three different scenarios are considered. Under the first scenario, the economy is hit by a $1 \%$ reduction in GDP, but experiences an increase in GDP of $1 \%$ in the subsequent quarter. The take-up rate of STW is assumed to remain constant at $1 \%$ during the downturn and the recovery. Under the second scenario, the economy is also hit by a temporary decline in GDP of $1 \%$, but in this case the economy recovers only after four quarters. As before, the take-up rate is assumed to remain constant during the downturn and the recovery. The third scenario is similar to the second scenario in that it also relates to a more prolonged downturn, but differs in that it assumes no STW in the recovery. In order to get an idea of the effectiveness of STW in these different scenarios, the cumulative difference in average hours worked with and without STW during the downturn is interpreted as a measure of the use of STW (up to $t=1$ in the first scenario and $t+4$ in the other two scenarios). Comparing this with the cumulative difference in employment over the first eight quarters provides an indication of the effectiveness of STW. To the extent that the cumulative difference in employment falls short of the cumulative difference in average hours worked, this may indicate that some jobs have been supported that either did not need support or were not viable anyway. Figure 2 presents the evolution of employment, total hours and average hours of permanent workers in the eight quarters that follow the initial decline in GDP.

- Under the first scenario in which the economy is hit by a short temporary reduction in GDP, the employment impact associated with STW appears to be relatively small compared with its impact on working time. While the difference in working time associated with STW is $0.25 \%$ (up to $t=1$ ), the cumulative difference in employment is only $0.07 \%$ (up to $t=8$ ). This suggests that the deadweight loss associated with short-time work in the context of a very short downturn may be over $70 \%((0.25-$ 0.07)/0.25). The relatively small impact of STW on employment reflects the fact that employment tends to respond to output shocks with a time lag. As a result, a relatively large fraction of jobs is supported that would be preserved anyway. The net impact of STW on employment is zero after four quarters.

- In the context of a prolonged downturn as under the second scenario, the impact of STW on employment is larger and STW tends to be more effective. Compared with the first scenario, the cumulative impact of STW on employment increases from $0.1 \%$ to $0.3 \%$ Moreover, STW tends to be somewhat more effective in 
Table 6 Dynamic results of the impact of STW on unemployment rates

\begin{tabular}{|c|c|c|c|c|c|c|c|}
\hline & & \multicolumn{3}{|c|}{ Change in unemployment benefit recipiency rate } & \multicolumn{3}{|c|}{$\begin{array}{l}\text { Change in ILO unemployment } \\
\text { rate }\end{array}$} \\
\hline & & $\begin{array}{l}\text { Model 1: } \\
\text { OLS }\end{array}$ & $\begin{array}{l}\text { Model 2: } \\
\text { OLS with } \\
\text { institutions }\end{array}$ & $\begin{array}{l}\text { Model 3: } \\
\text { IV with } \\
\text { institutions }\end{array}$ & Model 1: OLS & $\begin{array}{l}\text { Model 2: } \\
\text { OLS with } \\
\text { institutions }\end{array}$ & $\begin{array}{l}\text { Model 3: } \\
\text { IV with } \\
\text { institutions }\end{array}$ \\
\hline \multirow{2}{*}{\multicolumn{2}{|c|}{$\begin{array}{l}\text { Lagged dependent } \\
\text { variable in level }\end{array}$}} & -0.020 & -0.028 & -0.022 & -0.009 & -0.015 & 0.02 \\
\hline & & $(0.020)$ & $(0.017)$ & $(0.018$ & $(0.015)$ & $(0.014)$ & $(0.012)$ \\
\hline \multirow[t]{2}{*}{ Output } & & 0.003 & 0.006 & 0.024 & $0.020 * *$ & $0.023 * * *$ & 0.015 \\
\hline & & $(0.006)$ & $(0.007)$ & $(0.019)$ & $(0.008)$ & $(0.008)$ & $(0.011)$ \\
\hline \multirow[t]{6}{*}{ Output growth } & $\mathrm{t}$ & $-0.066^{* * *}$ & -0.056 & 0.097 & $-0.130 * * *$ & -0.083 & 0.112 \\
\hline & & $(0.023)$ & $(0.046)$ & $(0.152)$ & $(0.019)$ & $(0.054)$ & $(0.101)$ \\
\hline & $\mathrm{t}-1$ & $-0.087^{* * *}$ & $-0.112 * *$ & $-0.101 * *$ & $-0.136^{* * *}$ & -0.070 & -0.026 \\
\hline & & $(0.019)$ & $(0.049)$ & $(0.050)$ & $(0.021)$ & $(0.047)$ & $(0.074)$ \\
\hline & $\mathrm{t}-2$ & $-0.041 *$ & -0.025 & 0.020 & $-0.107^{* * *}$ & $-0.086^{*}$ & -0.017 \\
\hline & & $(0.021)$ & $(0.042)$ & $(0.059)$ & $(0.023)$ & $(0.047)$ & $(0.062)$ \\
\hline \multirow[t]{6}{*}{ STW take-up rate } & t & 0.001 & 0.000 & -0.011 & -0.001 & -0.001 & -0.004 \\
\hline & & $(0.001)$ & $(0.001)$ & $(0.009)$ & $(0.001)$ & $(0.001)$ & $(0.005)$ \\
\hline & $\mathrm{t}-1$ & -0.001 & -0.001 & 0.001 & 0.002 & 0.001 & -0.003 \\
\hline & & $(0.001)$ & $(0.001)$ & $(0.002)$ & $(0.001)$ & $(0.001)$ & $(0.002)$ \\
\hline & $t-2$ & $0.002 * *$ & $0.001 *$ & -0.001 & -0.001 & -0.001 & -0.001 \\
\hline & & $(0.001)$ & $(0.001)$ & $(0.001)$ & $(0.001)$ & $(0.001)$ & $(0.001)$ \\
\hline \multirow{5}{*}{$\begin{array}{l}\text { Output growth } \\
\text { times STW } \\
\text { take-up rate }\end{array}$} & $\mathrm{t}$ & -0.008 & 0.015 & $0.033^{*}$ & 0.026 & 0.032 & 0.028 \\
\hline & & $(0.018)$ & $(0.016)$ & $(0.018)$ & $(0.021)$ & $(0.021)$ & $(0.028)$ \\
\hline & $\mathrm{t}-1$ & -0.014 & 0.005 & $0.038 * *$ & $0.056^{* * *}$ & $0.053 * * *$ & $0.080 * * *$ \\
\hline & & $(0.014)$ & $(0.014)$ & $(0.019)$ & $(0.017)$ & $(0.019)$ & $(0.026)$ \\
\hline & $\mathrm{t}-2$ & $0.021 *$ & $0.032 * * *$ & $0.046^{* *}$ & 0.031 & $0.039 *$ & 0.020 \\
\hline
\end{tabular}


Table 6 Dynamic results of the impact of STW on unemployment rates (Continued)

\begin{tabular}{|c|c|c|c|c|c|c|c|}
\hline & & $(0.012)$ & $(0.011)$ & $(0.017)$ & $(0.020)$ & $(0.020)$ & $(0.032)$ \\
\hline \multirow{6}{*}{$\begin{array}{l}\text { Overall strictness } \\
\text { of employment } \\
\text { protection }\end{array}$} & $\mathrm{t}$ & & -0.001 & 0.012 & & 0.003 & 0.011 \\
\hline & & & $(0.005)$ & $(0.010)$ & & $(0.005)$ & $(0.010)$ \\
\hline & $t-1$ & & -0.001 & -0.005 & & 0.001 & 0.001 \\
\hline & & & $(0.006)$ & $(0.006)$ & & $(0.006)$ & (0.009) \\
\hline & $t-2$ & & -0.003 & 0.000 & & -0.003 & -0.005 \\
\hline & & & $(0.004)$ & $(0.004)$ & & $(0.003)$ & $(0.005)$ \\
\hline \multirow{6}{*}{$\begin{array}{l}\text { Output growth } \\
\text { times overall } \\
\text { strictness } \\
\text { of employment } \\
\text { protectionOu }\end{array}$} & $\mathrm{t}$ & & 0.025 & -0.008 & & -0.034 & -0.064 \\
\hline & & & $(0.024)$ & $(0.049)$ & & $(0.028)$ & $(0.044)$ \\
\hline & $t-1$ & & 0.031 & 0.042 & & 0.000 & -0.033 \\
\hline & & & $(0.028)$ & $(0.031)$ & & $(0.027)$ & $(0.034)$ \\
\hline & $t-2$ & & 0.017 & -0.012 & & -0.026 & -0.004 \\
\hline & & & $(0.021)$ & $(0.026)$ & & $(0.024)$ & $(0.027)$ \\
\hline \multirow{6}{*}{$\begin{array}{l}\text { UB net replacement } \\
\text { rate (average over } \\
60 \text { months) }\end{array}$} & $\mathrm{t}$ & & $0.000 * *$ & $0.000^{* *}$ & & 0.000 & 0.000 \\
\hline & & & $(0.000)$ & $(0.000)$ & & $(0.000)$ & $(0.000)$ \\
\hline & $t-1$ & & 0.000 & 0.000 & & 0.000 & 0.000 \\
\hline & & & $(0.000)$ & $(0.000)$ & & $(0.000)$ & $(0.000)$ \\
\hline & $t-2$ & & 0.000 & 0.000 & & 0.000 & 0.000 \\
\hline & & & $(0.000)$ & $(0.000)$ & & $(0.000)$ & $(0.000)$ \\
\hline \multirow{6}{*}{$\begin{array}{l}\text { Output growth } \\
\text { times UB net } \\
\text { replacement rate } \\
\text { (average over } \\
60 \text { months) }\end{array}$} & $\mathrm{t}$ & & $-0.002^{* *}$ & $-0.004^{* *}$ & & 0.001 & -0.001 \\
\hline & & & $(0.001)$ & $(0.002)$ & & $(0.001)$ & $(0.001)$ \\
\hline & $t-1$ & & $-0.002 *$ & $-0.003 * * *$ & & $-0.002 * *$ & -0.001 \\
\hline & & & $(0.001)$ & $(0.001)$ & & $(0.001)$ & $(0.001)$ \\
\hline & $t-2$ & & $-0.002 * * *$ & $-0.002 * * *$ & & 0.000 & -0.001 \\
\hline & & & $(0.001)$ & $(0.001)$ & & $(0.001)$ & $(0.001)$ \\
\hline
\end{tabular}


Table 6 Dynamic results of the impact of STW on unemployment rates (Continued)

\begin{tabular}{|c|c|c|c|c|c|c|}
\hline $\begin{array}{l}\text { Number of } \\
\text { countries }\end{array}$ & 23 & 23 & 13 & 23 & 23 & 13 \\
\hline $\begin{array}{l}\text { Number of } \\
\text { observations }\end{array}$ & 372 & 367 & 210 & 592 & 576 & 383 \\
\hline R-squared & 0.819 & 0.868 & 0.890 & 0.618 & 0.671 & 0.602 \\
\hline
\end{tabular}

Robust standard errors in brackets. Regressions include country time quarter dummies and year dummies.

a) Output in logs.

***,**,*: Statistically significant at the $1 \%, 5 \%$ and $10 \%$ level, respectively.

Source: Authors' estimates. 


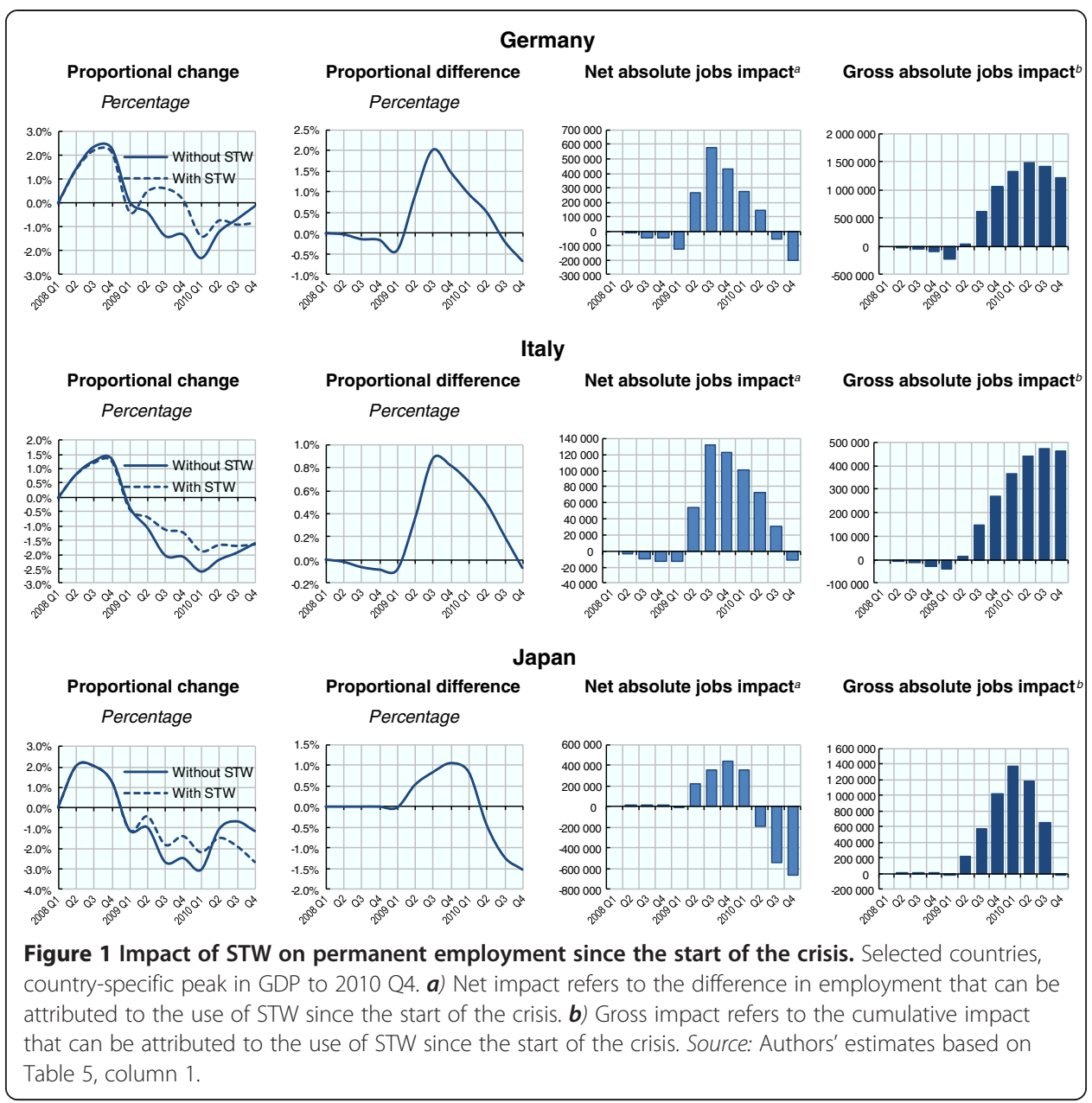

prolonged recessions since this increases the likelihood that jobs are supported that would have been suppressed otherwise. The cumulative impact of STW on employment $(0.3 \%$ up to $t=8)$ relative to that on average hours $(0.9 \%$ up to $t=4)$ suggests that deadweight costs may be two-thirds of the overall costs. The net impact of STW on employment is zero after six quarters.

- In the context of a prolonged downturn where the take-up rate of STW is only positive during the downturn, and is zero in the recovery, STW has a larger impact on employment in gross terms, has a more persistent net impact on employment and appears to be more effective. The cumulative impact of STW on employment is $0.4 \%$ (up to $t=8$ ). Given its impact on average hours ( $0.9 \%$ up to $t=4$ since the use of STW is assumed to be zero beyond), the deadweight losses associated with STW may be about half of the overall cost. The net impact of STW on employment is still positive after eight quarters as employment only converges slowly to its long-term trend. Thus, the balance of STW is considerably more positive if its use is limited to economic downturns. This is likely to be true in terms of its social, economic and fiscal costs. Given the prolonged nature of the global crisis in most countries and the relatively strong responsiveness of the intensity of STW to the improvement in economic conditions in the recovery (see the beginning of this sub-section), the third scenario may best describe the role of STW during the global financial crisis. This confirms 
the positive role that STW played in many OECD countries. However, it also implies that the role of STW in future downturns may not necessarily be as positive as was the case this time as it both depends on the nature of the crisis and the responsiveness of STW to economic conditions. The institutional design of STW programmes needs to take this into account ${ }^{14}$.

\section{Conclusions}

There has been a strong interest in short-time work (STW) schemes during the global financial crisis. Using data for 23 OECD countries, this paper analyses the quantitative effects of STW programmes on labour market outcomes by exploiting the country and time variation in STW take-up rates. The analysis takes account of differences in institutional settings across countries that might affect the relationship between labour market outcomes and output and addresses the potential endogeneity of STW take-up with respect to labour market conditions using the age of the programme as an instrument. Moreover, special attention is given to model the dynamic aspects of the relationship between output and labour market outcomes.

The results indicate the STW raises hours flexibility by increasing the contemporaneous output elasticity of working time and helps to preserve jobs in the context of a recession by making employment and unemployment less elastic with respect to output. A key finding is that the timing of STW is crucial. Short-time work schemes had a significant impact on preserving jobs during the crisis. The largest impact is observed in Germany, Italy and Japan where in the second half of 2009 employment is estimated to have been, respectively, 580.000, 130.000 and 445.000 higher than what it would have in the absence of STW. However, the same estimates also suggest that the continued use of STW during the recovery exerted a negative influence over the job-content of the recovery. As a result, the net effect on employment has fallen importantly in the recovery and in a few countries even has become negative.

Nevertheless, even in countries where the net impact has become negative, STW may still have played a very important role in limiting the social costs of the crisis. Indeed, the social impact of STW on employment, which is best measured in gross terms (the sum of the number of jobs saved in each time period), was substantial and positive in almost all countries. The impact of STW schemes is likely to be considerably more positive if their use is limited to economic downturns. This is likely to be true in terms of its social, economic and fiscal costs: it would have a larger positive impact on the number of jobs saved in each period; it would help sustain the positive net effects of STW crisis for longer during the recovery; and it would enhance the effectiveness of STW schemes.

In order to limit the use of STW to economic downturns, its use has to be very responsive to changes in economic conditions, both negative and positive. Factors that may help to ensure that take-up does not persist for too long in a recovery are to require firms to participate in the cost of STW, to limit the maximum duration of STW schemes and to require workers to search for a job whilst on STW.

\section{Endnotes}

${ }^{1}$ Bargain et al. (2012) provide simulation evidence that suggests that adjustment on the intensive margin (working time), tends to be associated with higher levels of welfare than adjustment on the extensive margin (employment). 


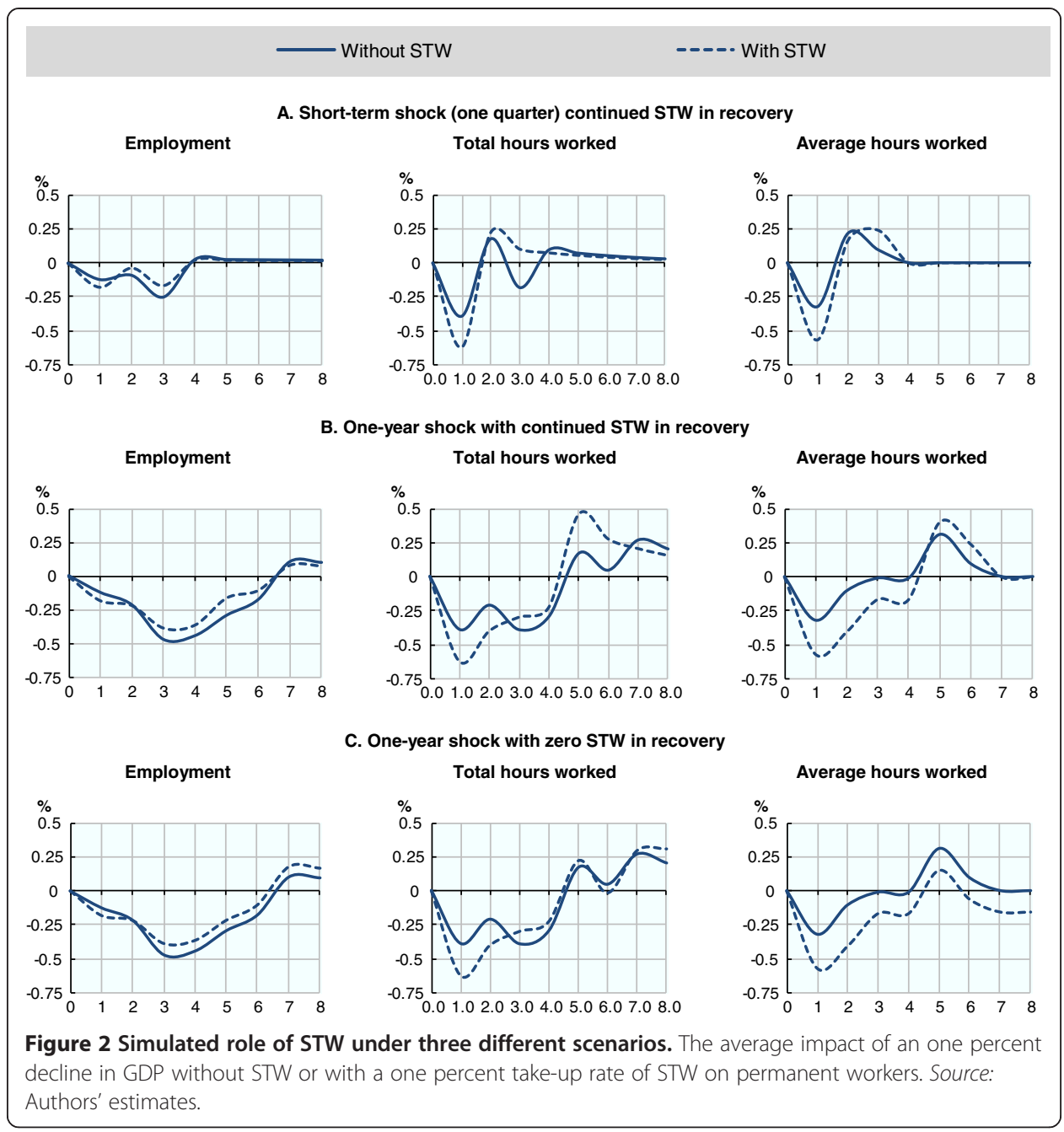

${ }^{2}$ The 2010 is the latest year for which comparable information on the use of STW has been collected by the OECD on a systematic basis.

${ }^{3}$ Calavrezo et al. (2009a and b) make use of French firm-level data from before the global financial crisis to analyse the impact of the STW (chômage partiel) on layoffs and firm survival. They find that chômage partiel tends to increase layoffs and reduce firm survival. This may indicate that despite the use of sophisticated econometric methods, the problem of selection bias has not been entirely removed. Berkeley Planning Associates \& Mathematica Policy Research, Inc. (1997) provide a comprehensive assessment of shorttime compensation programmes in the United States using a variety of methods and conclude that the available firm-level data do not allow one to reliably attribute differences in outcomes between participating and control firms to short-time compensation.

${ }^{4}$ See also Arpaia et al. (2010) for an early analysis of short-time work schemes.

${ }^{5}$ Five of these countries are considered for the purposes of the analysis not to operate STW schemes. These are respectively Estonia, Greece, Sweden, the United Kingdom and the United States. Greece only has a programme that deals with shortfalls in demand for seasonal or exceptional reasons and is therefore not considered as having a STW scheme for the purposes of this paper. In the United States, STW schemes 
operated in seventeen states during the crisis, covering about half the labour force. As the use of STW in those states was rather limited (Hijzen and Venn, 2010) and appropriate data to measure the use of take-up over time are not available, the United States was considered not to have a scheme for the purposes of the analysis in this paper .

${ }^{6}$ This may occur when firms have sufficiently strong incentives to retain redundant workers during the period of reduced output demand or when private arrangements between social partners are made to limit job losses (e.g. time-banking).

${ }^{7}$ It is well know that least squares dummy variable models with a lagged dependent variable yield inconsistent when $\mathrm{N}$ (the number of countries in this case) goes to infinity and the number of time periods is help fixed (Nickell, 1981). However, Judson and Owen (1999) show that such models yield reasonable estimates as long as the number time periods is reasonably large (i.e. 20-30) as in the present case (the maximum number of periods per country is 28).

${ }^{8}$ This excludes Korea, New Zealand, Slovenia, Turkey and the United States. The use of short-time work was negligible in New Zealand and the United States, modest in Korea and rather important in Slovenia and Turkey.

9 The differences between the coefficients on output changes in the total-hours equation and the sum of the corresponding coefficients in the employment and average-hours equations largely reflect the fact that average hours are modelled somewhat differently.

${ }^{10}$ Boeri and Brucker (2011) find stronger evidence of a direct negative effect on employment.

${ }^{11}$ This corresponds to an average hours reduction of about 25\%. Comparing this with direct figures on the average reduction in working time among STW participants reported in Hijzen and Venn (2010) suggests this estimate is reasonable, although perhaps somewhat on the low side.

12 The start of the crisis is defined by the country-specific peak of GDP.

${ }^{13}$ A look at Additional file 1: Figure A1 explains why the negative net impact at 2010 Q4 is so negative. The rise of in take-up only really started once the economic started to recover. This reflects a combination of various factors: the very sharp and sudden decline in GDP; the relatively slow response in STW to the decline in output; and a fast and steep initial recovery in GDP.

${ }^{14}$ The measure of social impact is also useful when assessing the fiscal benefits in terms of the reduction in unemployment-benefit payments. In order to get to the net fiscal impact, these benefits need to be balanced against the STW subsidies paid to firms.

${ }^{15}$ The present analysis effectively assumes that firms that make use of STW schemes in the recovery face improving business conditions, even though this may not be the case in practice. To the extent that firms with deteriorating business conditions are the ones that continue to make use of STW schemes during the recovery, the current analysis over-emphasizes the potential negative effects of STW schemes in the recovery.

${ }^{16}$ It is not straightforward to draw any conclusions about the effectiveness of short-time work schemes in individual countries. The labour market effects of STW may differ importantly across countries, because of differences in the average reduction in working time per STW participants, because of differences in the institutional features of short-time work schemes, differences in the institutional context in which STW schemes operate and the sectoral composition of employment and output changes. 


\section{Additional file}

Additional file 1: Table A1. Sources and definitions of short-time work schemes data. Figure A1. Stock of participants in STW schemes, 2007 Q1 to 2010 Q4.

\section{Competing interests}

The IZA Journal of Labor Policy is committed to the IZA Guiding Principles of Research Integrity. The authors declare that they have observed these principles.

\section{Acknowledgements}

This paper was prepared as part of a broader OECD project on «The role of policies for labour market resilience». The views expressed in this paper are those of the authors and cannot be attributed to the OECD or its member states. The authors would like to thank Mark Keese, Paul Swaim, Danielle Venn and Josef Zweimuller and one anonymous referee for helpful comments and suggestions. Financial support from the European Commission under grant number VS2010/0617 - SI576449 is gratefully acknowledged. All remaining errors are our own. For any queries in relation to this paper the authors can be contacted on the following email addresses: alexander.hijzen@oecd.org [Alexander Hijzen] and sebastien.martin@oecd.org [Sebastien Martin]

The Responsible Editor is: Juan Francisco Jimeno.

\section{Author details}

${ }^{1}$ OECD and IZA, Paris, France. ${ }^{2}$ OECD, Paris, France.

\section{Received: 8 January 2013 Accepted: 21 March 2013}

Published: 29 April 2013

\section{References}

Abraham K, Houseman S (1994) Does employment protection inhibit labor market flexibility? lessons from germany, france, and belgium. In: Blank R (ed) Social protection versus economic flexibility: is there a trade-off? University of Chicago Press, Chicago, pp 59-94

Arpaia A, Curci N, Meyermans E, Peschner J, Pierini F (2010) "Short time working arrangements as response to cyclical fluctuations". European Economy Occasional Paper No. 64. European Commission

Bellmann L, Gerner H-D, Upward R (2012) "The response of german establishments to the 2008-2009 economic crisis". OECD Social, Employment and Migration Working Papers, No. 137

Berkeley Planning Associates and Mathematica Policy Research, Inc (1997) "Evaluation of short-time compensation programs: final report", unemployment insurance occasional paper no. 97-3, us department of labour. Employment and Training Administration, Washington

Bils M (1987) "The cyclical behavior of marginal cost and price". Am Econ Rev 77(5):838-855

Boeri T, Bruecker H (2011) "Short-time work benefits revisited: some lessons from the global financial crisis". Economic Policy 26(Issue 68):697-765

Braun H, Brügemann B, Michalek K (2011) "Welfare effects of short-time compensation". presented at IZA Workshop "Unemployment Insurance in the Recession"

Burdett K, Wright R (1989) "Unemployment insurance and short-time compensation: the effects on layoffs, hours per worker, and wages". J Polit Econ 97(6):1479-1496

Caballero RJ, Engel EMRA, Haltiwanger J (1997) "Aggregate employment dynamics: building from microeconomic evidence". Am Econ Rev 87(1):115-137

Cahuc P, Carcillo S (2011) "Is short-time work a good method to keep unemployment down?". Nordic Econ Policy Rev No. 1:133-169

Calavrezo O, Duhautois R, Walkoviak E (2009a) "Chômage partiel et licenciements économiques", Connaissance de l'emploi. Centre d'études de l'emploi, p 4, No. 63

Calavrezo O, Duhautois R, Walkoviak E (2009b) "Short-time compensation and establishment survival: an empirical analysis with french data", comparative analysis of enterprise data (caed), conference, 2-4 October. Tokyo, Japan

Hijzen A, Venn D (2010) "The role of short-time work schemes during the 2008-09 recession", Oecd social, employment and migration working papers no. 2010/15. OECD Publishing, Paris

Judson RA, Owen AL (1999) Estimating dynamic panel data models: a guide for macroeconomists. Econ Lett 65:53-78

Nickell SJ (1981) Biases in dynamic models with fixed effects. Econometrica 49:1417-1426

OECD (2009) OECD employment outlook. OECD Publishing, Paris

OECD (2010) OECD employment outlook. OECD Publishing, Paris

Van Audenrode MA (1994) "Short-time compensation, Job security, and employment contracts: evidence from selected OECD countries". J Polit Econ 102:76-102

doi:10.1186/2193-9004-2-5

Cite this article as: Hijzen and Martin: The role of short-time work schemes during the global financial crisis 1 and early recovery: a cross-country analysis. IZA Journal of Labor Policy 2013 2:5. 